\title{
АКСІОЛОГІЧНІ ЗАСАДИ СИСТЕМИ ОСВІТИ КРАЇН ЗАХІДНОЇ ЄВРОПИ
}

\author{
(C) Лупаренко С.Є, 2020 \\ http://orcid.org/0000-0002-3111-5340 \\ http://doi.org/10.34142/2312-2471.2020.63.11
}

Статтю присвячено розкриттю аксіологічних засад системи освіти у країнах Західної Свропи. Наголошено на важливості формування цінностей у молодого покоління, оскільки вони є своєрідною «сировиною», яка впливає на розвиток мотиваційно-поведінкової і чуттєво-емоційної сфер особистості та формування соичуму загалом. 3'ясовано, щзо європейські країни спираються на ліберальні цінності й права людини, щуо становлять аксіологічні стовпи системи освіти цे розвитку європейського суспільства. Визначено основні цінності, на формування яких спрямовується система освіти у краӥнах Західної Свропи, а саме: рівність для всіх людей як основна європейська иінність; солідарність; гуманізм, який розглядає людину як абсолютну иінність; права людини; толерантність до різних соціальних та культурних груп; свобода, яка проголошує людину вільною від впливу держсавної влади, релігійної ієрархї тощуо; представництво та верховенства право; демократія; недискримінація; антирасизм; інклюзивне суспільство; міжособистісні стосунки; мир $i$ міжнародне взаєморозуміння; міжкультурна освіта; екологічна обізнаність тощуо. Установлено, щуо у процесі формування цінностей важливою $\epsilon$ національна орієнтація цүінностей, щзо спричинена історичними, політичними, релігійними, культурними та соџіальними особливостями системи освіти в різних країнах Західної Європи. Відзначено, щзо ефективними иляхами формування иінностей особистості у краӥнах Західної Свропи є: викладання ціннісно-орієнтованих навчальних дисциплін; інтеграція суміжних навчальних дисциилін; міжпредметні заходи, щуо встановлюють зв'язок із громадою; демократична культура закладу освіти, щуо включає орієнтачію на використання в навчанні діалогічних форм взаємодії суб'єктів освітнього прочесу; інклюзивна освіта, щзо об 'єднує різні групи учнів та вчителів; участь дітей у повсякденній практичній діяльності та спеціальних ситуаціях колективного управління, які створюються ц̌ контролюються іншими учасниками освітнього процесу (батьками, учителями, священиками).

Ключові слова: цінності, ліберальні цінності, аксіологія, аксіологічний підхід, освіта, Західна Свропа, гуманізм, права людини, толерантність.

\section{Luparenko S.Ye. Axiological Foundations of the Education Systems in the Countries of Western Europe}

The article is dedicated to the demonstration of the axiological foundations of the education systems in the countries of Western Europe. The author has focused on 
the importance of values formation for the younger generation, as values are a kind of "raw material" that influences the development of a person's motivationalbehavioral and sensory-emotional spheres and society formation in general. It has been found that European countries rely on liberal values and human rights, which are the axiological basis of the education system and development of the European society. The author has determined the main values, the formation of which is provided by the education system in the countries of Western Europe. They are equality for all people as the main European value; solidarity; humanism, according to which a man is considered to be the absolute value; human rights; tolerance for different social and cultural groups; freedom, which declares a person free from the influence of state power, religious hierarchy etc.; representation and the law rule; democracy; non-discrimination; anti-racism; inclusive society; interpersonal relationships; peace and international understanding; intercultural education; environmental awareness etc. It has been determined that national orientation of values is of particular importance in the process of person's values formation. It is caused by historical, political, religious, cultural and social peculiarities of the education system in different countries in Western Europe. The author has identified the effective ways of person's values formation in the countries of Western Europe. They are: teaching specific value-oriented subjects; integration of related subjects; interdisciplinary activities, which establish contact with the community; democratic culture of educational institutions, which includes focus on the use of dialogic forms of participants' interaction in learning; inclusive education that brings different groups of students and teachers together; students' participation in daily practical activities and special collective-management situations, which are created and controlled by other participants of the educational process (parents, teachers, priests).

Key words: values, liberal values, axiology, axiological approach, education, Western Europe, humanism, human rights, tolerance.

Постановка проблеми. Сучасна освіта постає соціальним інститутом, система цінностей якого значною мірою впливає на формування особистих цінностей людини та суспільних цінностей, загалом. Тому вибір провідних для освітньої діяльності цінностей має суттєве значення для подальшого розвитку соціуму.

Водночас, навколишній світ постійно змінюється, стає більш складним, а панорама цінностей у суспільстві - більш широкою й суперечливою. Проте саме цінності є основною «сировиною», яка створює та формує соціум [14].

Особливого значення аксіологічний підхід набуває в забезпеченні подальшої гуманізації системи освіти, адже він на основі визнання безумовної цінності кожного суб'єкта орієнтує педагогічну взаємодію на всебічний розвиток особистості, створення сприятливих умов для розвитку ії сутнісних сил, індивідуальних інтересів і потреб.

Цей підхід забезпечує загальну спрямованість освітнього процесу на засвоєння молоддю провідних суспільних цінностей, переведення їх на рівень персональних ціннісних пріоритетів. У свою чергу, це допомагає особистості 
адекватно поводитися в суспільстві, що динамічно змінюється, накопичувати досвід поведінки в умовах альтернативного вибору [6].

Система освіти країн Західної Свропи перебуває у стані реформування в напрямі подальшої інтеграції, демократизації та модернізації. Суперечки виникають стосовно політичних, соціальних та економічних рішень у галузі освіти, ролі національного елемента у процедурах прийняття рішень в об'єднаній Європі. Однак єдиним незаперечним моментом $\epsilon$ той факт, що Європа представляє собою специфічну аксіологічні спільноту, засновану на спільних фундаментальних цінностях, принципах, культурних зразках і досвіді [9].

3 огляду на це доцільним є вивченні аксіологічних засад системи освіти Західної Свропи задля виокремлення основних цінностей, на формування яких спрямовується освітній процес у них, і вивчення педагогічно цінного досвіду провадження ціннісно-орієнтованої освіти.

Аналіз останніх досліджень і публікацій. Необхідно підкреслити, що певні аспекти аксіологічних засад сучасної системи освіти досліджувалися вітчизняними та зарубіжними науковцями. Так, Р. Винничук, Л. Кравченко [2], Н. Ткачовою [7] висвітлено становлення аксіологічного підходу в історичній ретроспективі. А. Євдотюк [3], О. Базалук, О. П. Кравченко і Л. М. Харченко [1] розкривають аксіологічні засади сучасної системи освіти в Україні, у цілому. К. Левківська [5], Т. Калюжна й О. Уваркіна [4] вивчають питання аксіології в умовах модернізації різних закладів освіти.

Щодо зарубіжних науковців, основними напрямами досліджень $є$ : формування європейської системи освіти та суспільства, загалом, на аксіологічних засадах (D. Bunikowski [8], S. Drelich [9], F. Parra-Luna [14]) організація освітнього процесу на аксіологічних засадах (A. Kiryakova, G. Melekesov, T. Olkhovaya, A. Presnov [12], P. Paolicchi [13]), навчання цінностям у закладах освіти (I. Groot, V. Stolk, W. Veugelers [15], A. Valeev, I. Kondrateva [16]).

Виділення невирішених раніше частин загальної проблеми. Недостатньо вивченими залишаються питання загальних аксіологічних засад системи освіти країн Західної Європи, які ще не стали предметом дослідження вчених, що і зумовило наш науковий пошук.

Мета статті - розкрити аксіологічні засади системи освіти у країнах Західної Європи.

Виклад основного матеріалу. Ключовою категорією в педагогіці $\epsilon$ цінність - позитивне значення об'єктів навколишнього світу чи ідей для суспільства, соціальної групи або окремої особистості. Цінності виникають під час практичної діяльності людей, коли вони не лише пізнають властивості соціальних i природних явищ, але й намагаються дати їм оцінку з точки зору встановлення їхньої користі (або шкідливості) для власного життя. У масштабі життєдіяльності окремої особистості цінності виступають результатом іï суб'єктивної оцінки i тісно пов'язані з їі мотиваційно-поведінковою й чуттєво-емоційною сферами.

3 огляду на це, аксіологія визначається як теорія цінностей. Вона передбачає формування в особистості ціннісних орієнтацій, які задають загальну спрямованість іi інтересам i прагненням, ієрархію індивідуальних переваг, мотиваційну програму діяльності тощо [6]. 
На практиці формування особистісних цінностей $є$ дуже складним i багатоаспектним процесом, результати якого можна спрогнозувати тільки 3 певною долею вірогідності. Більш того, у реальному житті вчинки людини обумовлюються не тільки ii ціннісними пріоритетами, але й дією різних опосередкованих чинників, що може призвести до суттєвих відмінностей отриманих результатах від запланованих. Отже, під час формування особистих цінностей людини треба якомога повніше врахувати, які суттєві зовнішні фактори (середовище, виховання, діяльність тощо) впливають на цей процес.

У світлі Паризької декларації про сприяння громадянству та загальних цінностей свободи, толерантності та недискримінації через освіту одним із завдань сталого розвитку суспільства визначено забезпечення всеосяжної та якісної освіти для всіх та сприяння навчанню протягом усього життя. Просування спільних фундаментальних цінностей в освіті та через освіту має включати принципи демократичного громадянства. Життя у світі, що постійно змінюється, означає не лише адаптацію та асиміляцію до змін.

Активне громадянство, засноване на демократичних принципах, передбачає також, що громадяни можуть активно формувати та змінювати суспільство. Кожне покоління повинно вчитися i мати можливості реалізовувати демократичні принципи, цінності, ідеї та основні концепції прав та обов'язків. 3 огляду на це освіта відіграє провідну роль у просуванні спільних цінностей та вихованні відданих, критично мислячих та активних громадян [11].

Процес формування цінностей особистості в системі освіти країн Західної Європи зумовлюється низкою факторів, як-то: швидкі зміни у глобальному масштабі, у світі, загалом, що спричиняє необхідність змін у системі освіти; збільшення етнічного і культурного різноманіття; провідне місце релігії; посилення акценту на громадянстві та демократії; орієнтація на національні ідеї (у кожній окремій країні) тощо.

Слід зауважити, що європейські країни спираються на ліберальні цінності і права людини $[2 ; 5 ; 8]$, які становлять аксіологічні стовпи системи освіти й розвитку європейського співтовариства у цілому. Серед основних цінностей, на формування яких спрямовується система освіти у країнах Західної Свропи, $є$ такі $[9 ; 11 ; 15]$ :

- рівність для всіх людей як основна європейська цінність;

- солідарність;

- толерантність до різних соціальних та культурних груп;

- права людини - природні права, але для їх захисту запроваджено незліченну кількість правових та міжнародних норм [9];

- гуманізм, який розглядає людину як істоту, що самовдосконалюється, абсолютну цінність. Він сприяє розвитку освіти та запускає механізми прогресу на шляху досягнення власних цілей;

- свобода, яка проголошує людину вільною від впливу будь-якої соціальної групи, державної влади, релігійної ієрархії тощо. Спільність свободи та толерантності гарантують не лише право людини самостійно приймати 
рішення стосовно свого життя, але й покладають на суспільство зобов'язання поважати такі індивідуальні рішення [9];

- представництво та верховенства право;

- демократія;

- недискримінація;

- антирасизм;

- інклюзивне суспільство;

- міжособистісні стосунки;

- мир і міжнародне взаєморозуміння;

- міжкультурна освіта;

- екологічна обізнаність тощо.

Водночас, формування таких цінностей, як свобода, недискримінація, рівність і солідарність $є$ особливо складним через різноманітність політичних, історичних, релігійних, культурних та соціальних національних контекстів у країнах Західної Європи [11]. Зі створенням і розвитком Свропейського Союзу освітні системи європейських країн стають більш схожими.

Ця тенденція виявляється щонайменше 3 моменту створення Ради Свропи у 1949 р. та Європейського співтовариства у 1967 р. Важливою також є цінність історичного розвитку кожної нації, підтримка мовного та культурного різноманіття особистості. Утім, Рада Європи зацікавлена у розвитку європейського виміру освіти. Мета цього процесу - не скасувати національні відмінності на користь європейської ідентичності, а прагнути до єдності в piзноманітності. Європейський Союз завжди наголошував на важливості цінностей демократії та толерантності для Європи як спільноти і для іiі державчленів [10]. 3 огляду на це, у процесі формування цінностей особистості важливою $є$ орієнтація не лише на загальновизнані цінності, але й національні цінності $[9 ; 15]$.

Дійсно, історія політичного та соціального розвитку різних країн може спричинити певні відмінності в їхній конкретній ціннісній ієрархії та організації системи освіти; ціннісна освіта тісно пов'язана 3 політичним розвитком країни, оскільки кожен уряд підкреслює різні цінності.

Однак, системи освіти західноєвропейських країн виявляють більш-менш певну схожість стосовно цінностей у процесі реформування навчальних програм. Вони відображають соціальні та ідеологічні зміни у країні і свідчать про сильний європейський рух до демократії та особистої орієнтації системи освіти.

Ці проблеми є актуальними сучасними викликами для системи освіти європейських країн. Освіта може бути використана як інструмент утиску чи розширення можливостей етнічних, соціальних та політичних меншин. Педагоги мають бути уважними до вимог, що висуваються суспільством до якості освітніх послуг, до своєї відповідальності та усвідомлення власної ролі в освітньому процесі.

Співіснування різноманітних етнічних груп та культур у роздробленості постмодерністських суспільств можна зберегти і без важкого клейма культурної чи етнічної «різниці», а радше завдяки педагогами, які з повагою ставляться до 
національних особливостей учнів та визначають можливості й потенційні ресурси для врахування культурного різноманіття у своїх класах і групах [13].

Ціннісний розвиток учнів здійснюється завдяки загальноосвітньому підходу, який включає формування цінностей декількома способами: викладання конкретних ціннісно-орієнтованих навчальних дисциплін; інтеграція суміжних навчальних дисциплін; міжпредметні заходи, що встановлюють зв’язок із громадою; демократична культура закладу освіти, що включає орієнтацію на переважне використання в навчанні діалогічних форм взаємодії суб'єктів освітнього процесу; інклюзивна освіта, що об'єднує різні групи учнів та вчителів [15].

Окрім того, у кожному суспільстві цінності утверджуються та передаються завдяки участі учнів у повсякденній практичній діяльності та спеціальних ситуаціях колективного управління, які створюються й контролюються інституційними «місцевими охоронцями морального порядку» (батьками, учителями, священиками) [13].

Висновки. Отже, аксіологічні засади системи освіти країн Західної Свропи складають ліберальні цінності і права людини (рівність для всіх людей, солідарність, гуманізм, толерантність до різних соціальних та культурних груп, свобода, представництво та верховенство права, демократія, недискримінація, антирасизм, інклюзивне суспільство, міжособистісні стосунки, мир і міжнародне взаєморозуміння, міжкультурна освіта, екологічна обізнаність тощо).

Окрім того, у процесі формування цінностей особистості важливою є й національна орієнтація цінностей, що зумовлена політичними, історичними, релігійними, культурними та соціальними національними особливостями системи освіти в різних країнах Західної Свропи. Проведене дослідження не вичерпує всіх аспектів проблеми, що вивчається.

Перспективу їі подальшої розробки вбачаємо в розкритті аксіологічних засад вищої освіти, зокрема, в різних країнах Західної Свропи.

\section{Jimepamypa}

1. Базалук О.О., Кравченко О.П., Харченко Л.М. Аксіологічні засади сучасної системи освіти України. Переяслав-Хмельницький : «Видавництво КСB», 2019. 87 c.

2. Винничук Р., Кравченко Л. Аксіологічний підхід у вітчизняній педагогічній науці та практиці: історико-педагогічна ретроспектива. Витоки педагогічної майстерності : зб. наук. праць. Полтава : ПНПУ імені В.Г.Короленка, 2019. Вип. 23. С. 22-28. URL : https://doi.org/10.33989/2075-146x.2019.23.183168

3. Свдотюк А. Аксіологічні засади сучасної системи освіти в Україні. Педагогічний пошук. 2014. № 2(82). С. 12-15.

4. Калюжна Т.Г. Педагогічна аксіологія в умовах модернізації професійно-педагогічної освіти: монографія / за наук. ред. О.В. Уваркіної. Київ: Вид-во НПУ імені М.П.Драгоманова, 2012. 128 с.

5. Левківська К.В. Ціннісні засади діяльності освітніх закладів: навч.метод. посібн. Житомир: Вид-во ЖДУ імені Івана Франка, 2017. 136 с. 
6. Ткачова Н.О. Аксіологічний підхід. Наукові підходи до педагогічних досліджень : колективна монографія / за заг. ред. В.І. Лозової. Харків: Вид-во Віровець А. П. «Апостроф», 2012. С. 126-146.

7. Ткачова Н.О. Історія розвитку цінностей в освіті: монографія. Харків: ХНУ імені В.Н. Каразіна. 2004. 423 с.

8. Bunikowski D. Values and Axiology in the European Union Legal System in Context of the European Culture and the Constitution for Europe. Why does the EU Need the Axiology? $2013 . \quad$ URL: https://www.researchgate.net/publication/303971870

9. Drelich S. European Axiological Community: a Unity Impossible to Deny. 4Liberty. 2013. September 13. URL: http://4liberty.eu/european-axiologicalcommunity-a-unity-impossible-to-deny/

10. Educational Roots, Reform in the Twentieth Century, Contemporary Reform Trends, Future Challenges. URL: https://education.stateuniversity.com/pages/2547/Western-Europe.html

11. Joint Statement on Citizenship Education \& EU Common Values by the EU CONVINCE Project Partners. A Joint Initiative on Promoting EU Common Values and Inclusive Education. URL: https://www.esha.org/esha-projects/eucommon-values-and-inclusive-education/

12. Kiryakova A.V., Olkhovaya T.A., Melekesov G.A., Presnov A.A. The Axiological Approach to the Analysis of the Problems of Modern University Education. Mediterranean Journal of Social Sciences. 2015. Vol. 6. № 2(3). P. 2228.

13. Paolicchi P. Values-Education in Context. URL: http://good-id-inschools.eu/artikel/values-education-context

14. Parra-Luna F. Axiological Systems Theory. Encyclopedia of Life Support Systems. URL: https://www.eolss.net/Sample-Chapters/C02/E6-46-01-07.pdf

15. Veugelers W., Groot I., Stolk V. Teaching Common Values in Europe. 2017. URL: https://research4committees.blog/2017/03/15/teaching-common-values-in-europe-2/

16. Valeev, A.A., Kondrat'eva I.G. Axiological Approach to the Development of Students' Intercultural Competences by Foreign Language Means. Procedia Social and Behavioral Sciences. 2015. № 191. P. 361-365.

\section{References}

1. Bazaluk, O.O., Kravhenko, O.P., Kharchenko, L.M. (2019). Aksiolohichni zasady sychasnoi systemy osvity $v$ Ukraini [Axiological principles of the modern education system of Ukraine]. Pereyaslav-Khmelnytsky: «KSV».

2. Vynnychuk, R., Kravchenko, L. (2019). Aksiolohichnyi pidhid u vitchyznianiy pedahohichniy nautsi ta praktytsi: istoryko-pedahohichna retrospektyva [Axiological approach in domestic pedagogical science and practice: historical and pedagogical retrospective]. Vytoky pedahohichnoi maisternosi, 23, 22-28. Retrieved from https://doi.org/10.33989/2075-146x.2019.23.183168

3. Yevdotiuk, A. (2014). Aksiolohichni zasady sychasnoi systemy osvity v Ukraini [Axiological principles of the modern education system in Ukraine]. Pedahohichnyi poshuk, 2(82), 12-15. 
4. Kaliuzhna, T.G. (2012). Pedahohichna aksiologiia v umovah modernizatsii profesiyno-pedahohichnoi osvity [Pedagogical axiology in the conditions of modernization of professional and pedagogical education] / za red. O. V. Uvarkinoi. Kyiv: National Pedagogical Dragomanov University.

5. Levkivska, K.V. (2017). Tsinnisni zasady diialnosti osvitnih zakladiv [Values of activity of educational institutions]. Zhytomyr: Zhytomyr Ivan Franko State University.

6. Tkachova, N.O. (2012). Aksiolohichnyi pidhid [Axiological approach]. Naukovi pidhody do pedahohichnyh doslidzhen / za zag. red. V. I. Lozovoi. Kharkiv: «Apostrophe».

7. Tkachova, N.O. (2004). Istoriia rozvytku tsinnostei v osviti [History of the development of values in education]. Kharkiv: V.N. Karazin Kharkiv National University.

8. Bunikowski, D. (2013). Values and Axiology in the European Union Legal System in Context of the European Culture and the Constitution for Europe. Why does the EU Need the Axiology? Retrieved from https://www.researchgate.net/publication/303971870

9. Drelich, S. (2013). European Axiological Community: a Unity Impossible to Deny. 4Liberty, September 13. Retrieved from http://4liberty.eu/europeanaxiological-community-a-unity-impossible-to-deny/

10. Educational Roots, Reform in the Twentieth Century, Contemporary Reform Trends, Future Challenges. (n.d.). Retrieved from https://education.stateuniversity.com/pages/2547/Western-Europe.html

11. Joint Statement on Citizenship Education \& EU Common Values by the EU CONVINCE Project Partners. A Joint Initiative on Promoting EU Common Values and Inclusive Education. (n.d.). Retrieved from https://www.esha.org/eshaprojects/eu-common-values-and-inclusive-education/

12. Kiryakova, A.V., Olkhovaya, T.A., Melekesov, G.A., Presnov, A.A. (2015). The Axiological Approach to the Analysis of the Problems of Modern University Education. Mediterranean Journal of Social Sciences, 6, 2(3), 22-28.

13. Paolicchi, P. (n.d.). Values-Education in Context. Retrieved from http://good-id-in-schools.eu/artikel/values-education-context

14. Parra-Luna, F. (n.d.). Axiological Systems Theory. Encyclopedia of Life Support Systems. Retrieved from https://www.eolss.net/Sample-Chapters/C02/E6-4601-07.pdf

15. Veugelers, W., Groot, I., Stolk, V. (2017). Teaching Common Values in Europe. Retrieved from https://research4committees.blog/2017/03/15/teachingcommon-values-in-europe-2/

16. Valeev, A.A., Kondrat'eva, I.G. (2015). Axiological Approach to the Development of Students' Intercultural Competences by Foreign Language Means. Procedia - Social and Behavioral Sciences, 191, 361-365. 